\title{
竹富島における結願祭の祭祀空間に関する研究
}

一祭祀空間にみる祈願の分担方法について -

\section{STUDY ON THE SPATIAL CONSTRUCTION AND COMPOSITION OF THE "KITSUGAN" HARVEST FESTIVAL ON TAKETOMI ISLAND, YAEYAMA, OKINAWA \\ - Analysis relating to the system and function of the places of worship -}

金城 正 紀*

Masanori KINJYO

\begin{abstract}
This paper aims to analyze the spatial construction and composition of the "Kitsugan" harvest festival on Taketomi Island, Yaeyama, Okinawa.

There are lots of place of worship and six groups of prayers, Yamaninju, on Taketomi Island. Each group has a primary place of worship.

In order to clarify multi-function of each place of worship and ritual composition and procedure in each village, the relationship between (1)Yamaninju' s primary place of worship, (2)places of worship to which Yamaninju should pray, and (3)types and locations of the place of worship is analyzed in detail through a review of the performing procedure of the "Kitsugan" harvest ritual.

Data were collected and recorded from a series of field studies and literary reviews of the period.
\end{abstract}

Keywords : Okinawa, Taketomi Island, Festival, Ritual,

沖縄、竹富島、祭祀、儀礼

1 はじめに

南西諸島の集落には、拝所である御猚（ウタキ，オン，ワン，ウ ガン） 注》井戸 (カー)、来訪神歓待の場所（ニライカナイ，ニー ラン）などが点在する。なかでも御獤は、伝説的な英雄や祖神の 墓地、旧集落跡や島づくりの神を祀った場所が多く、様々な固有性 と機能を持つ。島の代表的な拝所には祭祀集団が所属し祭祀が行わ れ、それに伴う集落の空間認識や、神話や伝承に基づいた祭祀空間 の構造を捉えることができる。

一方で、扯所によっては複数の神を祀り、複合的な機能を持つも のもある注2)。また、本来御嶽と呼ばれていなかった拝所が、御获 と呼ばれるようになるケースや、遠くにある扯所を遙扯する場所と して一時的な拝所を仮設するケースもみられる注 3)。また拝所での 祭祀や祈願に、その拝所に所属しない祭祀集団が参加する場合があ る る $^{\text {注 }}$ 。

このように、1）拝所が本来持っていなかった機能・名称が付加 し、拝所の意味が変容・複合化したり、2）拝所に所属し管轄する

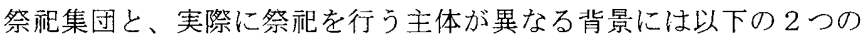
要因が挙げられよう。

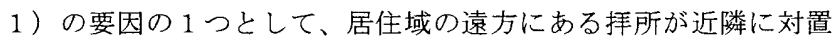
されたり、扯所と居住域のそれぞれの立地特性から新たな機能や名
称が付加されるなど、洋所と居住域の相対的な立地関係を背景に、 新たな空間認識が生じたためだと考えられる。すなわち、空間的な 要因によるものである。

また2）の要因の1つとして、公民館などの近代的な自治組織に よる祭祀運営の合理化や婚姻関係の複雑化、世襲制の衰退に伴う祭 祀集団の複雑化など、村落社会の近代化に伴って生じた複層的な所 属を背景に、祭祀の主体が再構成されたことが考えられる。すなわ ち、社会的な要因によるものである。

このように、拝所の意味や機能の変容 - 複合化と、拝所への所属 と祈願主体の相異からは、神話や伝承に基づいて秩序立てられた祭 祀空間の構造とは異なった祭祀空間の構造を検出することができ る。その祭和空間は、空間的・社会的要因を背景に構造化・再編さ れていると予想し、その要因を探求することを本研究の課題とした い。

そこで本稿は、様々な拝所や御嶽の類型と立地特性がみられ、年 間複数の祭祀行事が行われるなか、複数の祭祀集団が現れる、沖縄 県八重山郡竹富島の祭祀空間を題材に前記課題を検証する。

竹富島の御猫の立地特性と集落空間の関係を考察した研究では、 『沖縄八重山諸島の村落信仰における伝統的祭祀施設の空間構造に 関する研究 -聖なる空間の形態学序説一』(浦山隆一,1999 年) 注ら 
がある。この研究では、現居住域への草分け・後入りを背景に、旧 居住域を表徴する 6 つの祭祀集団の居住構成と、6力所の御猚（旧 居住跡）の位置関係の特性を捉えている。現居住域における祭祀集 団の居住構成の秩序が、現居住域の周縁にある旧居住跡の立地特性 から影響をうけていることを発見している。

現在、竹富島の祭祀行事では、6つの旧居住跡を表徵し、神話・ 伝承を背景として存在する祭祀集団は、穂利祭（プイ）と長月祝い （ナーキヨイ）の 2 つの祭祀以外には現れず、ほとんどの祭祀では 神職役と近代的な自治組織である公民館役員や村住人が祭祀に参加 している。また、拝所への所属と、実際にその拝所で新願をする祈 願主体の所属はすべて同一ではなく、祈願対象によって祈願主体が 構成されるため、両者の関係は複層的である注6)。すなわち、竹富 島におけるいくつかの祭祀は再編されている。

そこで、祭祀再編について論じた『変貌する祭祀 - 沖縄の女性祭 祀集団の持続と再編に関寸る一考察-』(渋谷研, 沖縄民俗研究第 14 号, 1994）注7)で渋谷は、《主体（担い手）>・<装置（組織）>・ ＜論理（世界観など）>の3つに視点を置いている。主にく主体 $>$ とく装置 $>$ の関係に変貌研究の視点を置き、これら祭祀変貌の背景 にはく論理＞に影響されたく装置>の改変があると言及する。この 研究注、集落の自治組織が近代化していく中で、実際に祈願する主 体が再構成され、祭祀が地域で内発的・積極的に維持されていく様 相を描きだそうとしており、その視点や分析方法は本稿に共通する 部分を持っている。

しかし、これら既往研究の考察には、洋所を一義的な場所・対象 として捉え、更にその場所・対象を実際に祈願する主体（祭祀集団） も一律な属性として捉えていることが前提にあり、择所が持ちうる 多義性や、祈願主体の複層的な属性を前提にした祭祀空間の考察が 希薄といえる。

そこで本稿は、竹富島の大祭の1つである「結願祭 (キツガン)」 を取り上げる。結願祭では、6つの旧居住域跡を表徵する祭祀集団 は現れないにも関わらず、その祭祀集団に所属する神職役と、現在 の居住域である 3 つの村を単位とした自治組織の役員が、島の代表 的な拝所の大半を祈願する。

神職役は祭祀集団に所属するだけでなく、 3つの村を単位としたいずれかの自治組織に も所属し、役員は自治組織に所属するだけで なく、いずれかの祭祀集団にも所属する。更 にこの祭祀では、6つの祭祀集団への所属 と、実際に御获へ祈願する祈願主体の構成は 同等ではない。

すなわち、結願祭の祭祀空間を研究題材と することで、拝所の多義性および、祈願主体 の複層的な属性とその構成が捉えられ、本稿 の課題である神話・伝承とは異なった隠れた 空間的要因あるいは社会的要因を探求するこ とができると考える。

研究の方法としては、まず結願祭の祭祀進 行にみる祈願ルートを基に祭祀空間の構造を 明らかにし、更にそれぞれの择所の立地特性 から見えてくる空間的秩序と拝所の多義性を
明らかにしたい。また、新願主体の祭祀集団（御孰）と自治組織（居 住構成）への所属から得られる祈願主体の複合的な属性と、それか ら見えてくる社会的秩序、および実際に場所・対象で祈願を行う祈 願主体の構成との関係を明らかにしたい。

すなわち本稿は、集落空閒や祭祀の構造を背景にみる祈願対象 （拝所）の位置と、近代的な村落社会の重層構造にみる祈願主体の 属性と構成㧈よび祈願の分担方法から、結願祭に隠れている空間 的・社会的な“構成秩序“を明らかにする研究である。

\section{2 集落空間と祭祀集団}

考察を行う前に、竹富島の集落空間と社会組織について、拝所の 類型・分布と御获および自治組織への所属に依拠してまとめてお $<$ 。

\section{1 竹富島の集落と拝所}

竹富島の居住域は島のほぼ中央に位置し、「ンブフル」という丘 を挟んで玻座間村と仲筋村から構成される。玻座間村は、村を南北 に貫く「ナビンドー」と呼ばれる道を挟んで、東屋敷に所在する東 村（アイノタ）と、西屋敷に所在する西村（インノタ）から構成さ れる。この東村・西村・仲筋村の区分は明治 36 年の人頭税廃止と 共に施行されたとされる注8)。居住域から島の沿岸部へは道が放射 状に延び、その道沿いに「御獤（オン)」や「ニーラン」注9) など の拝所が点在する（図 1)。

\section{2 拝所の類型と分布からみた集落空間}

公民館祭祀行事に関わる御嶽は、祭祀集団の所属や管理から大き

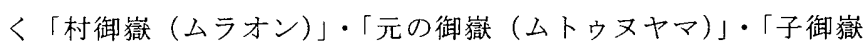
(ファーオン)」の 3 つの類型で捉えることができる（図 1)。村御

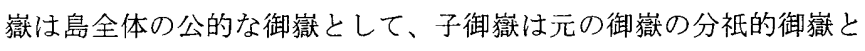
して、また両者は島の祭祀集団の御孰として位置づけられる注 10)。

また、これらの類型とは別に、島で代表的な择所としてニーラン、 真知御嵲、弥勒奉安殿があげられる。

ここでこれらの所在地をみると、村御譬は居住域に、元の御嶽は

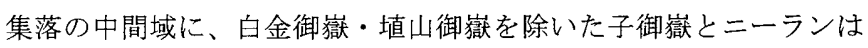
沿岸域に点在し、その他の真知御猰や弥勒奉安殿は居住域周辺に所
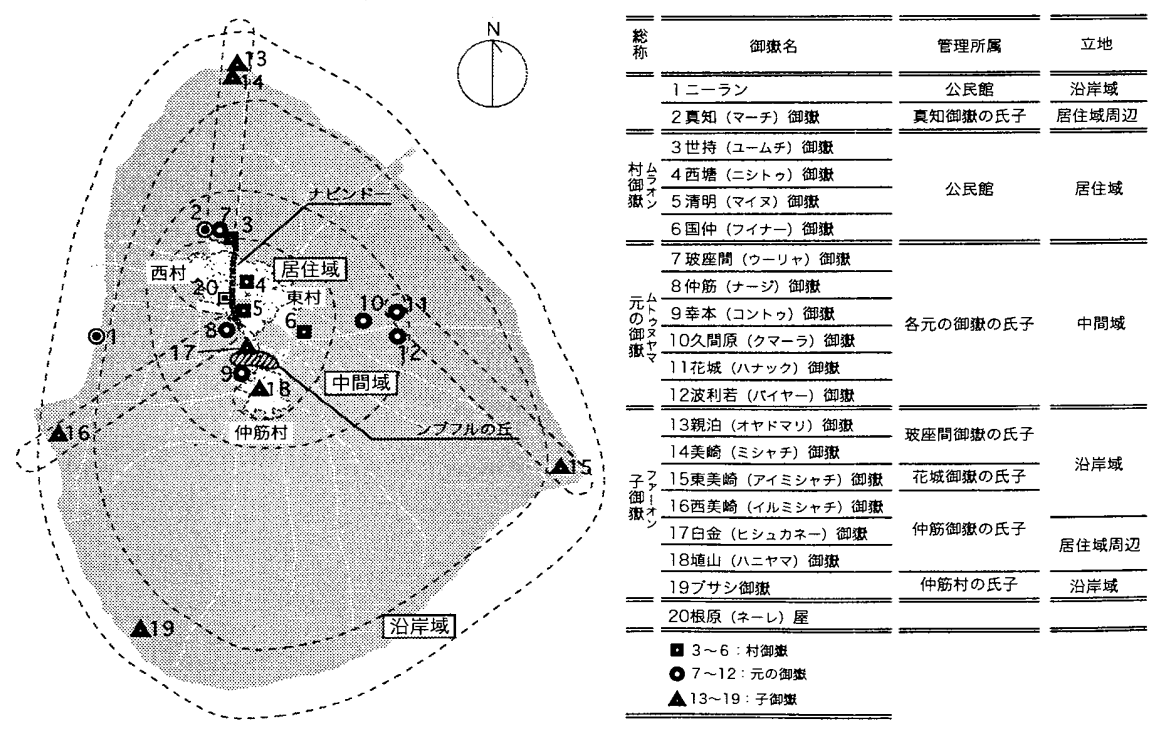

図 1 御獤の分布・類型と立地特性 


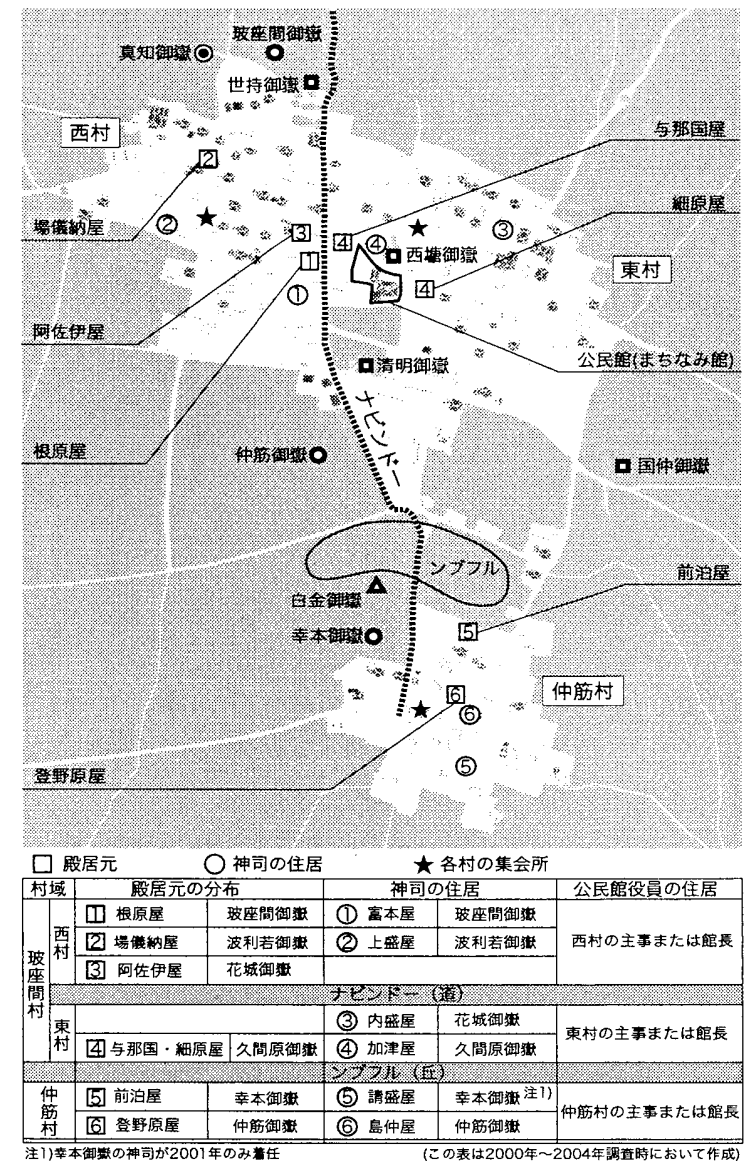

図 2 殿居元の分布および神司・公民館執行部の<居住構成 $>$

\section{在していることがわかる(図 1)。}

また、居住域の中間域・北側に立地する玻座間御嶽の子御嶽は、 同じ方角の沿岸域・北側に、中間域・東側に立地する花城御崔の子 御嶽は同じ方角の沿岸域・東側に、中間域・西側に立地する仲筋御 孰の子御獤は同じ方角の沿岸域・西側に立地している（図 1)。

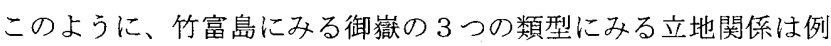
外があるもののほぼ同心円状に、更に一部の元の御猄とその分祇的 御嶽である子御获の立地関係は放射状になっており、御䇏の分布か らは二重の空間的秩序が捉えられる。

\section{3 御嶽の祭祀集団と居住構成}

いくつかの御猚には、「氏子（オンビ）」が所属する。6つの元の 御嶽の各々に所属する氏子集団を「山人数 (ヤマニンジュ)」と呼ぶ。 山人数の祭祀を司る神職役の氏子を「神司（カンツカサ）」と呼ぶ。 山人数は、それぞれの宗家である「殿居元（トゥニムゥト）」を持つ。 穂利祭と長月祝いでは、元の御猚と子御獤を一組として、それぞれ に所属する山人数が各々の御嶽を祈願・参择する注 ${ }^{11}$ 。

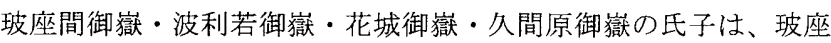
間村に多く居住し、仲筋御獤・幸本御獤の氏子は仲筋村に多く居住 するとされてきた注 ${ }^{122}$ 。現在の殿居元の所在をみると、玻座間御該・ 波利若御嶽・花城御啍の殿居元は西村に、久間原御嶽の殿居元は東 村に、仲筋御获・幸本御嶽の殿居元は仲筋村に所在する。加えて現 在は、玻座間御獤・波利若御猚の神司が西村に、花城御嶽・久間原

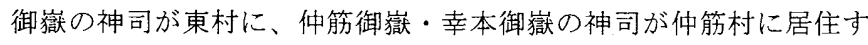
る(図 2 上段)。
このように、殿居元の立地と神司の居住位置の構成関係をみる と、玻座間村と仲筋村の 2 つに区分できる。しかし、花城御獤の殿 居元が西村に、神司の住居が東村にあることから、東村・西村・仲

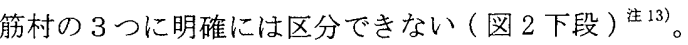

\section{4 自治組織と村住人の居住構成}

公民館の祭祀行事には、集落の自治組織である「公民館執行部」 が参加し、祭祀集団の役目を担 5 。公民館執行部は、公民館長（1人)・ 主事 $(2$ 人) ・顧問 $(3$ 人の長老) ・有志 $(3$ 人) ・祭事部 $(3$ 人) で組 織される。公民館長は3つの村（東村・西村・仲筋村）から1人選ばれ、

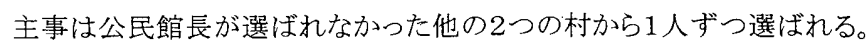
顧問・有志・祭事部は3つの村から1人ずつ選ばれる。

また村住人は、一部の祭祀において、3つの村単位（東村住人・西 村住人・仲筋村住人) で祭祀に参加しており、祭祀集団としての村住 人は、自治単位を基に構成されているといえる ${ }^{14)}$ 。

よって、祭祀集団としての村住人と公民館執行部の居住構成は、3 つの村（東村・西村・仲筋村）に明確に区分できる。

\section{5 氏子と村住人．公民館執行部の関係}

上記のように、同属の殿居元と神司の居住構成は 2 つ村（玻座 間村·仲筋村）に、村住人と公民館執行部の居住構成は 3 つの村（東 村・西村・仲筋村）に明確に区分できることから、島の 6 つの元 の御猚に所属する殿居元・氏子の居住構成と、祭祀集団であり自治 単位を基に構成される村住人・公民館執行部の居住構成に相異がみ られる。また、6つの元の衘嶽に所属する氏子は、同時に村住人や 公民館執行部であることから、島の住人は 2 つの社会的な属性を持 つ。

このように、竹富島の祭祀集団と村の構成は、二重の社会的秩序 を背景に存在していることが解る注15)。

\section{3 結願祭の祭祀空間 3.1 結願祭の概要}

結願祭は、八重山地域に伝わる一連の豊年祀りの1つで、神司が 御嶽で夜籠もりを行うことや、いままでの願いいの感謝と、願解き が行われる湦 16)。また、村の代表的な御獤の神前で奉納芸能が行わ れることが一般的な特徴である。

竹富島の結願祭は、1875 年から行われており衤17)、旧暦 8 月ミズ ノエから 2 日間かけて行われる。本稿では、2004 年 9 月 $20 \cdot 21$ 日 に行われた結願祭の筆者らによる調查を基に考察を行っている。祭 祀におけるルートと、それぞれの祈願対象の位置と祈願主体の構成 を、2人で分担して調查記録を行った ${ }^{189}$ 。

\section{2 結願祭の祭祀空間}

結願祭 1 日目の夕刻から神司が、一晚御嶽の神と過ごす「夜籠も り(ユングマイ)」を行う。久間原御嶽・波利若御嶽の神司が西塘

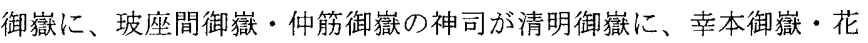
城御猚の神司が幸本御嶽に籠もる。その最中（夕刻過ぎ）に、公民 館執行部（館長・主事・顧問）が 3 カ所それぞれの御䔻で参詣を行 う(図 3)。

結願祭 2 日目は、早朝に、公民館執行部と大山家・与那国家の男 性主人が、弥勒奉安殿に集まり祈願を行う。その後、3 所の御猚 で夜籠もりをしていた神司全員と、弥勒の新願を終えた公民館執行 部が玻座間御嶽で合流し、玻座間御猚をはじめに、世持御获・仲筋 

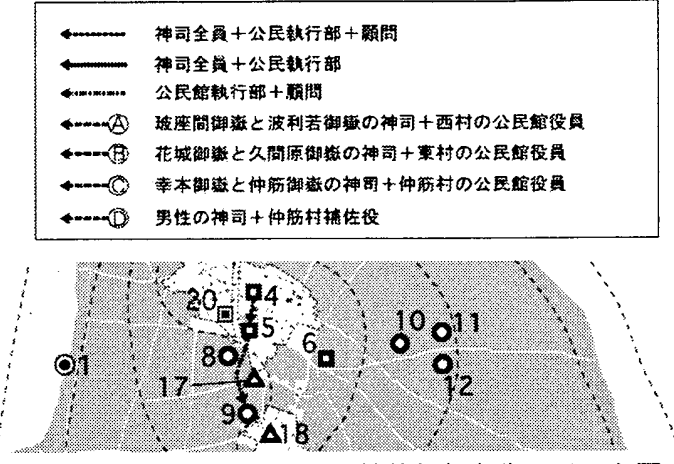

図3 結願祭 1 日目・公民館執行部参詣のルーート図

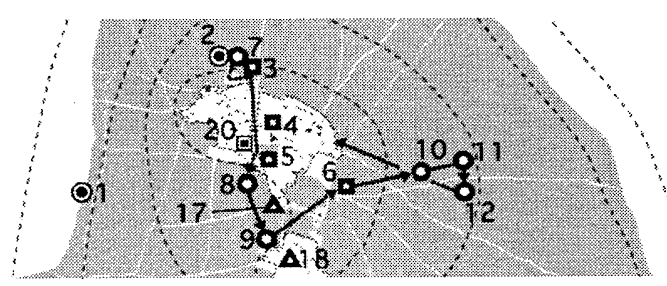

図4 結願祭 2 日目前半・神司と公民館執行部祈願のルート図

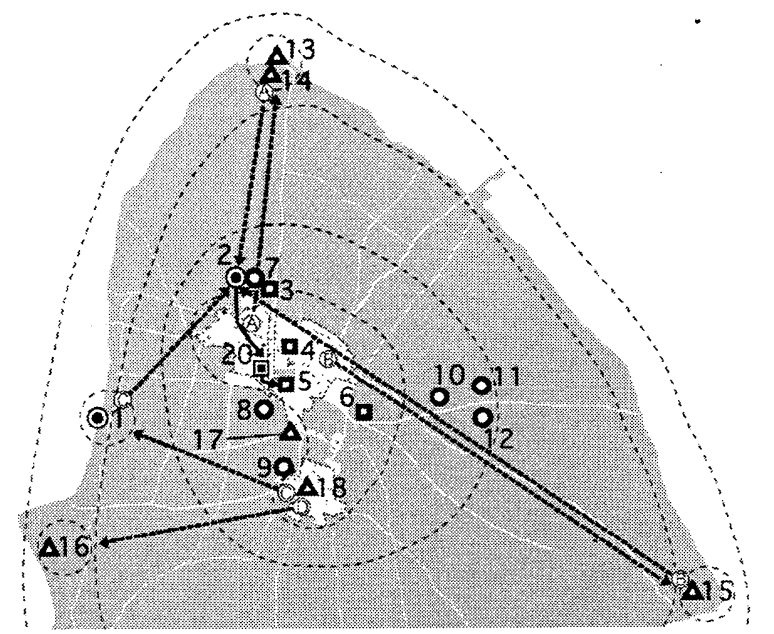

図 5 結願祭 2 日目後半・神司と公民館執行部祈願のルート図

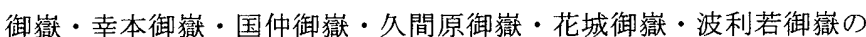
順で 8 力所の御獄を祈願して趈る（図 4)。
そして、玻座間御訔・波利若御嶽の神司と西村の主事は美崎御嶽・ 親泊御猫一、花城御猚・久間原御嶽の神司と東村の主事（兼館長） は東美崎御訔人、仲筋御嶽・幸本御獤の神司と仲筋村の主事はニー ランへそれぞれ分かれて祈願を行う。またこの時、仲筋村の男司が 西美崎御猚で祈願を行う ${ }^{\text {注 }}{ }^{19}$ ( 図 5)。

それぞれの拝所での祈願を終えた神司と公民館執行部は、真知御 聤に集合し、祈願を行う。その後、ナビンドーに面し 3 つの村の中 央に位置する根原屋（玻座閒御猚の殿居元）で祈願を行う。

一連の择所での祈願を終えた神司と公民館執行部は、島のほぼ中 央に位置し、島造りの神が祀られている清明御猋へと移動する。神 司全員が清明御莅での祈願を行った後、清明御獤の前に設営された 舞台で、各村による奉納芸能が催される（図 5)。

\section{3 祭祀空間の構造}

結願祭における祈願や儀礼は、西塘御獤・清明御嶽・幸本御嶽が 点在する集落の居住域周辺から、玻座間御獤・世持御嶽・仲筋御嶽・

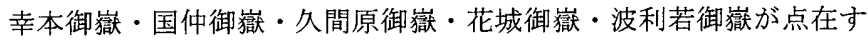
る中間域周辺一移動し、その後分かれて美崎御獤・親泊御獤・東美 崎御嶽・ニーラン・西美崎御訔が点在する沿岸域へと移動している。 そして、真知御孰で合流し新願を行った後、集落の中心にあり村立 てを象徵する根原屋を新願し、最後に奉納芸能が行われる清明御猚 一と移動している。

このように、結願祭の祭祀空間は、集落の中心（居住域・居住域 周辺）から始まり周縁（中間域・沿岸域）八移動し、再度集落の中 心（居住域・居住域周辺）に移動しており、御猚の立地特性からみ た集落の同心円状という空間的秩序に基づいて構成されていること が伺える (表 1 下段)。

\section{4 祭祀再編と祈願の分担方法}

\section{1 祈願対象と祈願主体の複層的な関係}

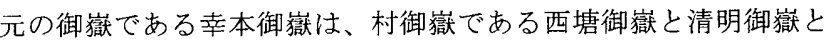
並んで夜籠もりの御該として機能していることからも、村御孰に類

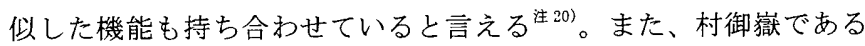
国仲御藃・世持御詁と並んで 6 力所の元の御獤を、それぞれの元の 御嶽に所属しない他の神司も含めた神司全員と公民館執行部が同伴

表 1 <祈願対象の所属・管理 >および結願祭の祭祀空間と＜祈願主体の構成 $>$ の関係

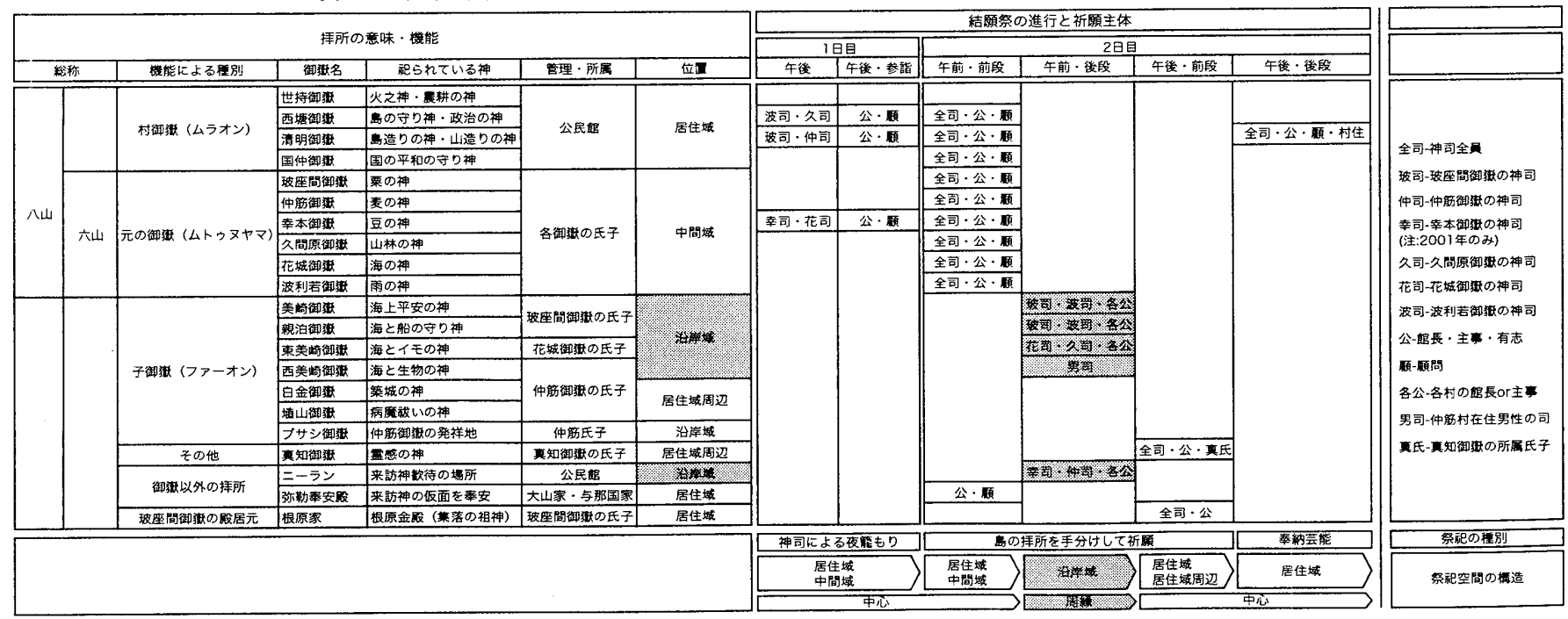


して新願している。このように祈願対象と新願主体の関係にみる祈 願方法からは、元の御猚が氏子の御崔として機能しているだけでな く、村御孰としての機能をも持ち合わせていることが伺える（表 1)。 更に、沿岸域に点在する子御訔とニーランを、所属する神司と所属 しない神司・公民館執行部（館長・主事 2 人）が分かれて祈願を行っ ている(表 1)。

氏子集団が現れる穂利祭と長月祝いでは、元の御嶽と元の御㒛の 分祇的拝所である子御㠍を、それぞれに所属する氏子集団が主体と なり祈願を行う。すなわち、この 2 つの祭祀においては、元の御藃 と子御获での<祈願主体の構成 $>$ と元の御获への所属 $>$ は一致し ている。

しかし、氏子集団が現れない結願祭においては、<新願主体の構 成 $>$ と<元の御偝一の所属 $>$ 関係は複層的で、特に沿岸域の数カ 所の拝所においては、それぞれに異なったく祈願主体の構成〉がみ られる。

\section{2 沿岸域における拝所の多義性}

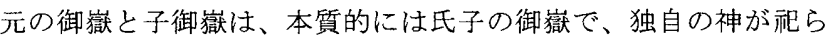
れ、それぞれ異なった意味や機能を持っている。また、ニーランは 来訪神歓待の場所として機能している(表 1)。

しかし聞き取りによれば、結願祭において沿岸域の 4 力所の子御 嶽とニーランを、神司・男性の司・公民館執行部（館長・主事）が して祈願する目的は、集落の四隅を守護する祈りをするためである という注21)。すなわち、沿岸部に点在する子御猚とニーランは、そ れぞれ独自の意味や機能を持つだけでなく、島の 4 隅を守護する場 所としても機能しているのである。（表 1・図 5)。

このようなことから沿岸域にある拝所は、結願祭の祭祀空間が中 心 $\rightarrow$ 周縁 $\rightarrow$ 中と移動する祭祀空間の構造、あるいは择所の類型と 点在状況から見えてくる居住域 - 中間域一沿岸域といら同心円状の

表 2 <祈願主体の属性〉と沿岸域の拝所におけるく祈願主体の構成＞
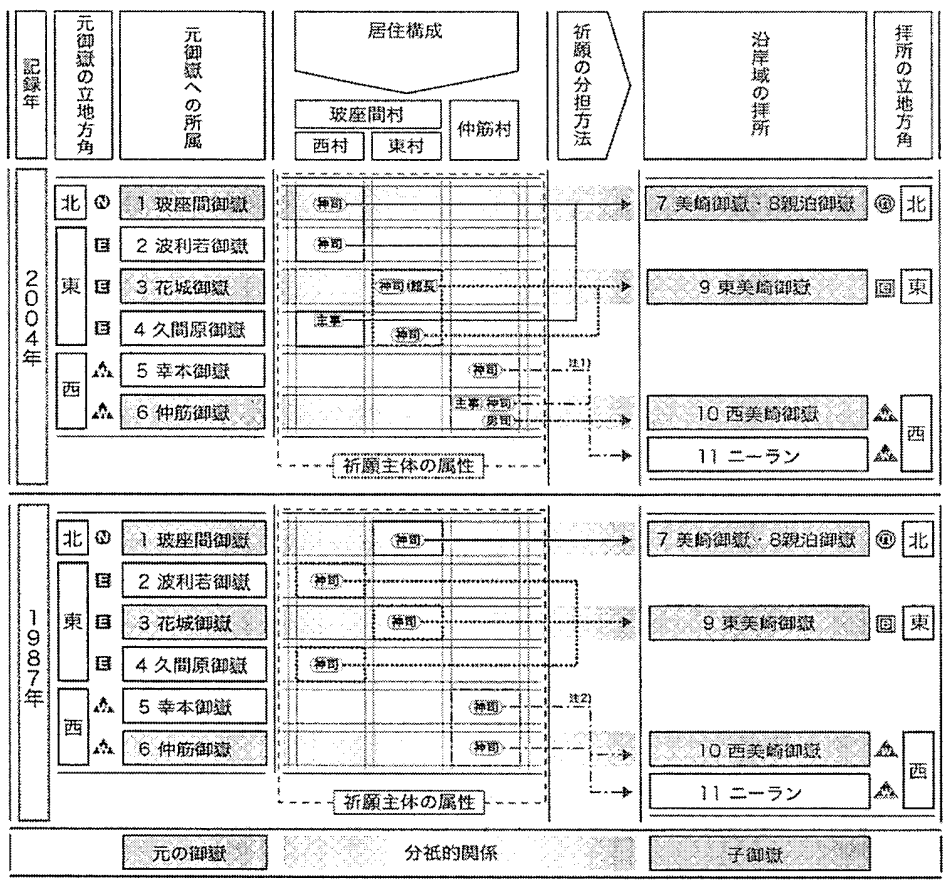

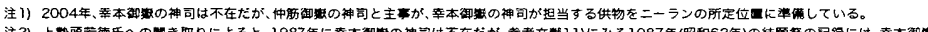

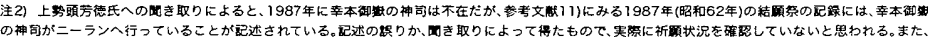

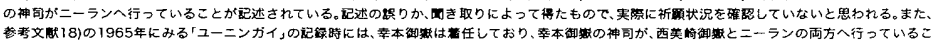
とがされている。
空間的秩序を背景に、集落における内一外の境界として見立てられ、

多義性を持った拝所であることが解る。

\section{3 沿岸域の拝所における祈願主体の構成}

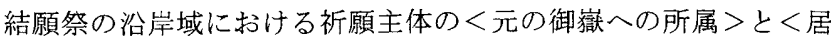
住構成 $>$ の関係、すなわち<祈願主体の属性 $>$ と<元の御獤の立地 方角 $>$ 関係を、表 2 左側に記した。また、沿岸域におけるく洋所 の立地方角 >を表 2 右側に記し、元の御孰と分祇的拝所である子御 獤との関倸をグラデーションで表現した。更に、沿岸域の择所にお けるく祈願主体の構成 $>$ とその分担方法を、<祈願の分担方法 $>$ と して矢印で示した（表 2)。

調査を行った 2004 年時点では、玻座間御鳎・波利若御孰の神司 は西村に、花城御猚・久間原御嶽の神司は東村に、幸本御嶽・仲筋 御获の神司は仲筋村にそれぞれ居住している(図 2 ・表 2 上段)。

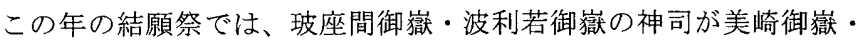
親泊御猚へ、久間原御䓂・花城御獤の神司が東美崎御嶽人、仲筋御 㠇・幸本御劦の神司がニーランへと分かれて祈願を行っている（表 2 上段)。

また、同行する東村の主事（兼館長・花城御薃一所属）は東美崎

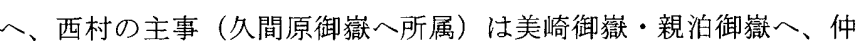
筋村の主事 (仲筋御䓂へ所属) はニーランへと分かれ、神司の補佐 および祈願を行っている（表 2 上段）。

表 2 上段に示す通り、<祈願主体の構成＞と＜祈願主体の属性> に複層的関係を捉えることができ、また結願祭の沿岸域の拝所にお

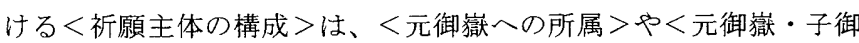
㠃の立地方角 $>$ に関係なく、東村に居住する祈願主体は東美崎御嵓 を、西村に居住する祈願主体は美崎御嶽・親泊御嶽を、仲筋村に居 住する祈願主体は西美崎御啍とニーランを新願している。

すなわち、2004 年の結願祭にみる沿岸域の择所にみられるく祈 願主体の構成＞は、＜居住構成＞に従っているように捉えら れる(表 2 上段)。

\section{4 祈願主体の構成とその再編}

1965 年の結願祭が記録されている『沖縄民俗』(琉球大学 民俗研究クラブ編・1988）と、1987 年の結願祭が記録され ている『竹富島の歷史と民俗』（亀井秀一・1990）によると、 子御䛦への祈願主体の構成が 2004 年とは異なる。玻座閒御

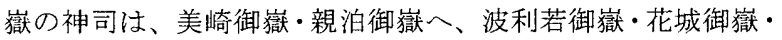
久間原御获の神司は東美崎御获一、仲筋御嶽の神司はニーラ ンへ分かれて祈願を行っていたことが記されている注22?。

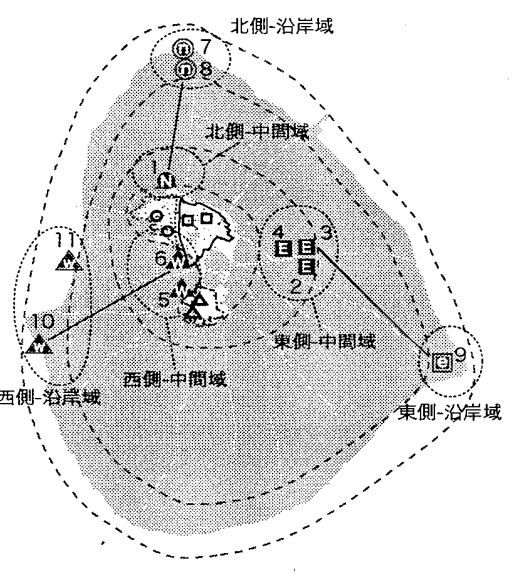

またこの当時、波 利若御孰・久間原御 嶽の神司は西村に、 玻座間御嶽・花城御 嶽の神司は東村に、 幸本御嶽・仲筋御訔 の神司は仲筋村にそ れぞれ居住していた (表 3) 注23)。

ここで、く祈願主 体の構成 $>$ と<新願 主体の属性＞にみる 


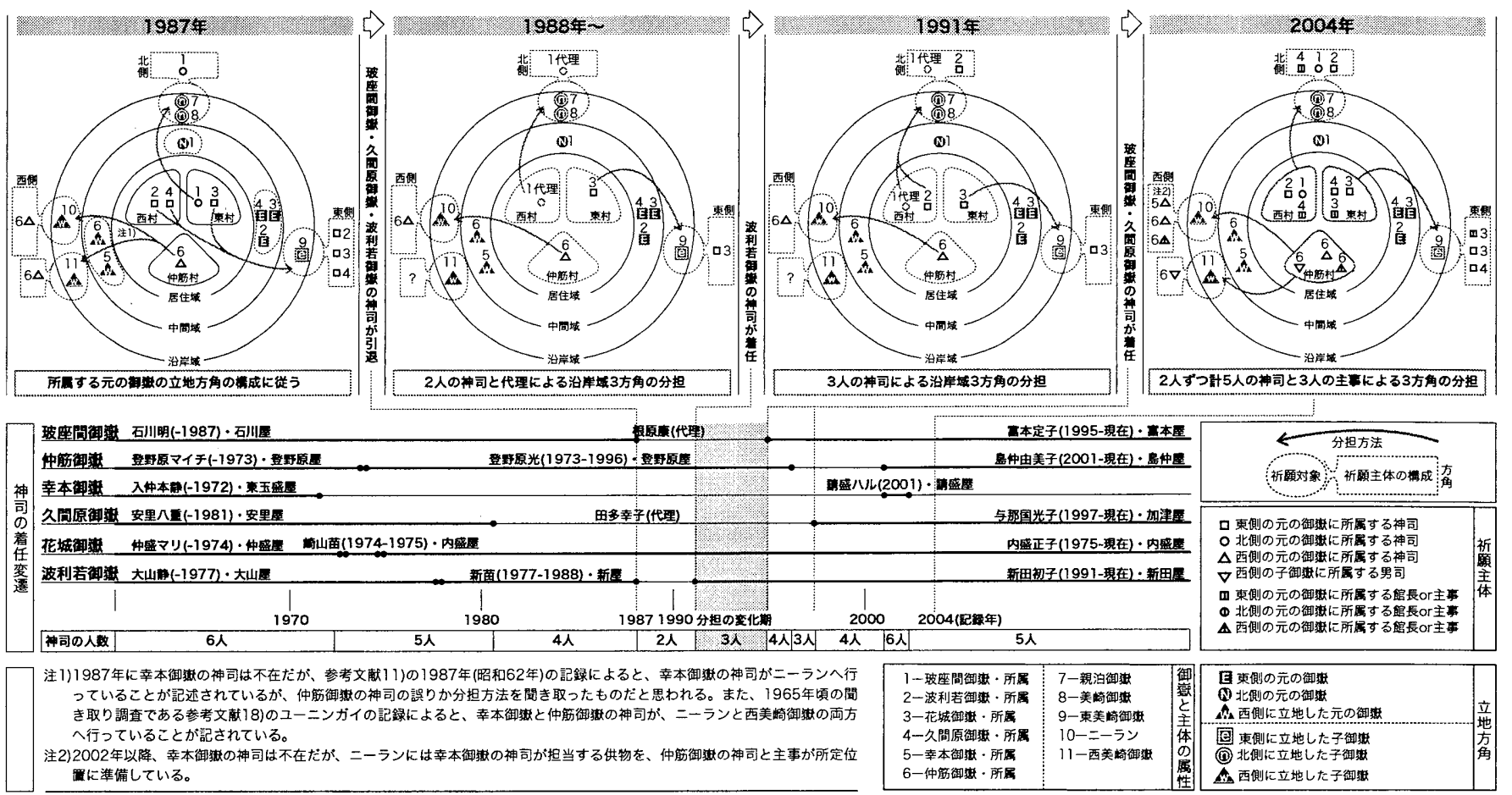

図 6 沿岸域の抨所における<祈願主体の構成 $>$ 再編と神司着任の变遷

複層的関係を、表 2 の 1987 年の下段に示した。表 2 下段からもわ かるように、1987 年当時の沿岸域の拝所におけるく祈願主体の構 成＞は、<元の御猚・子御嶽の立地方角 >を基に構成され、それぞ れの祈願対象は沿岸域におけるく扯所の立地方角〉に従っているよ うに捉えられ、2004 年の記録でみる沿岸域の择所にお括るく祈願 主体の構成＞が祈願主体の<居住構成＞に従う状況とは異なってい たことが解る(表 2 下段）。

このように、祈願主体の<元の御嶽への所属 $><$ 元の御獤・子御 猴の立地方角 $><$ 居住構成 $>$ に依拠し、結願祭の沿岸域の拝所にお けるく祈願主体の構成＞を考察してゆくと、<元の御获・子御猚の 立地方角 $>$ という放射状の空間的秩序から、《居住構成 $>$ 寸なわち 明治 36 年から施行された近代的な自治単位（東村・西村・仲筋村） という社会的秩序へと再編され、近年にみる分担方法になったよう に捉えられる(表 2)。

\section{5 神司継承にみる祈願主体再編の背景}

以前、神司が 6 人から 2 人へと減少する時期があった。玻座間御获・ 波利若御獤・久間原御嶽・幸本御获には、しばらく実質的な神司が 着任していなかった注24)。その後 1991 年に、波利若御訔の神司が 就任した。その年、沿岸域 3 方角の拝所（北側の美崎御獤と親泊御

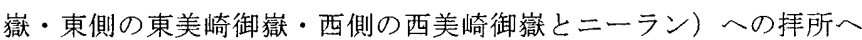

表 3 神司の居住構成

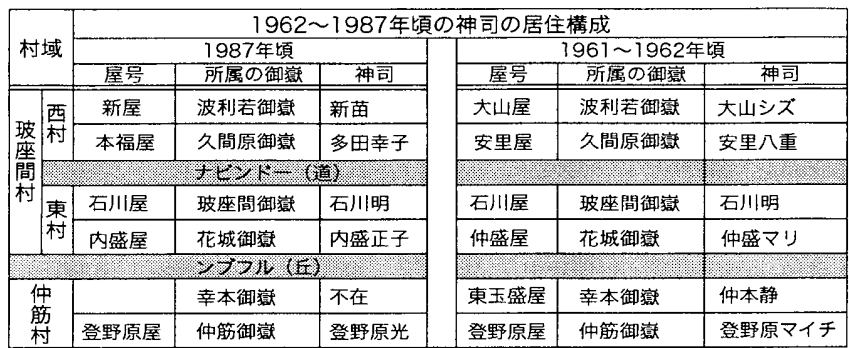

の祈願分担をする際に、波利若御嶽の神司が玻座間御獤の神司代理 と共に北側の美崎御聤・親泊御偝を祈願した。その後に着任した玻

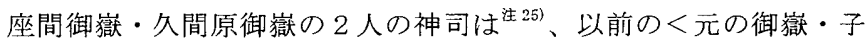
御嶽の立地方角>に従った分担方法で祈願するが、波利若御猚の神 司は引き続き北側の美崎御獤・親泊御嶽を新願し、現在のく祈願の 分担方法>に至っている注 ${ }^{26)}$ (図 6)。

このように現在の結願祭では、3つの村に居住する神司が 2 人ず つ、公民館長・主事が 1 人ずつ、それぞれ 3 方角へ分担して祈願す ることから、一見く居住構成（自治単位）>に依拠して祈䫝主体が 構成され、3方角の拝所の祈願を合理的に分担しているように捉え られる。

しかし、結願祭における沿岸域での祈願主体の構成再編の背景 には、神司不足の時期において特殊な分担方法が生じたことが起因 で、後に神司が増えた近年になって後天的に定着したく祈願の分担 方法 >とく祈願主体の構成＞が隠れていたことが解る（図 6)。

\section{5 結語}

本稿では、結願祭の祭祀空間の構造を背景に、祈願主体の<元の 御获一の所属 $>$ ・ 居住構成 $>$ から捉えられるく祈願主体の属性 $>$ と、<祈願主体の構成 $>$ ・ 拝所の立地方角 $>$ の関係を考察するこ とで、以下の点を明らかにすることができた。

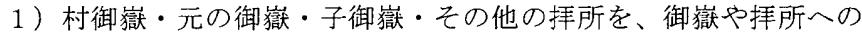
所属とは関係なく、神司と公民館執行部が同伴または分担して祈願 していることから、祈願対象への所属と新願主体の関係は複層的で ある。

2 ）沿岸域に点在する择所の一部は、それぞれ神話・伝承に基づい た独自の意味や機能だけでなく、拝所の立地特性や祭祀空間の構造 
から見えてくる同心円状の空間的秩序を背景に、集落における内一 外の境界として見立てられ、多義的な意味や機能を持つ。

3) 沿岸域の拝所におけるく祈願主体の構成>の背景にある構成 秩序は、以前所属する<元の御獤・子御㠇の立地方角 $>$ という放射 状の空間的秩序に従っており、近年になって祈願主体の<居住構成 (自治単位) >という社会的秩序へと従うようになったように捉え られる。しかしその起因は、神司の継承・着任の過程において特殊 なく祈願の分担方法＞が生じ、後天的に定着したく新願主体の構成 >であることが解った。

このように結願祭の祭萢空間における祈願対象の立地特性や、祈 願対象と祈願主体の複層的な関係を読み解くことで、神話・伝承に

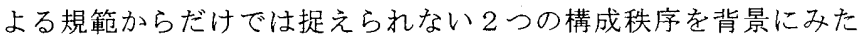
分担方法の変化が得られた。

\section{謝辞}

調査や資料作成にあたって支援と訂正を頂いた上勢頭芳徳氏（竹 富島喜宝院蒐集館館長）へ、また貴重な祭祀場面を特別に見せてい ただき、忙しいなか調查資料をチェック、聞き取りにお付き合いい ただいた神司の方々をはじめ、竹富島でお会いした多くの方々へ媣 く御礼を申し上げます。更に、本稿を仕上げるにあたり、的確なア ドバイス・ご指導をいただいた光井渉氏（東京芸術大学助教授）へ 媣く感謝を申し上げます。

\section{注}

注 1）「择所」は、一般的に「ウガン」または「ウガンジュ」と呼ばれる。参 考文献 1) pp. 306, 参考文献 2) 上巻 pp. 279 参照。また、「御嶽」は地域 によって呼称や機能、意味が異なる。参考文献 3) pp. 91-92，参考文献 4) pp. 15-16, 参考文献 5) pp. 124 参照。

注 2）集落創成に関わる代表的な拝所に、聖地巡礼である東迴り（アガイマー イ）・今帰仁迴り（ナキジンマーイ）を仮設する香炉が付属している例 がある (北中城村安谷屋「上の御孰」・筆者の調查による)。

注 3）墓所である「骨神（フニシン)」が、集落の東側にあることから、後年、 「東又御獤（アガリヌウタキ）」と呼ばれるようになった例がある（南風 原町津嘉山・参考文献 6) pp. 438 と筆者の調查による)。また、祭祀集団 が衰退しつつある近年において、多数の择所を少人数で合理的に廻るた め、集落の近場や代表的な拝所に、複数の遙拝香炉を設けている場合が ある(糸満市大里「南山城」・筆者の調査による)。

注 4）择所に所属する祭祀集団・親族や、集落の公民館役員が、祭祀行事に上っ て編成され、神職役の代理として、あるいは分担で扯所を新願する例が ある (北中城村安谷屋・糸満市大里)。

注 5) 参考文献 8) pp. 77-121 参照。

注 6) 参考文献 9) pp. 136-138 参照。

注 7) 参考文献 10) pp. 11-26 参照。

注 8）参考文献 11)pp. 112，参考文献 12）pp. 15 参照。

注 9）島に様々な種子を持ち込んだといわれるニーラン神の船のとも綱を掛け たと言い伝えられる石があり、来訪神を向かえる場所として機能してい る。参考文献 13) pp. 3-4 参照。

注 10）御猚の類型については、樣々な解釈と方法がある。参考文献 4) pp. 16-22, 参考文献 13) pp. 60-61 参照。本稿では、波照間永吉氏の分類方法である、

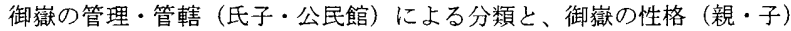
による分類の 2 つ方法を考慮し、3つの類型を設定している。

注 11) 年間祭祀行事のなかでも、山人数が現れる祭祀は、穂利祭の御獄穂利（才 ンプイ）と長月祝い(ナーキヨイ）だけである。参考文献 9) pp. 136-138， 参考文献 13) pp. 56 参照。

注 12）玻座間御猚を祖神とする共同体は、玻座間村の草分けで、波利若御訔。 花城御嶽・久間原御獤を祖神とする共同体は、玻座間村への後入りだと される。また、仲筋御猫を祖神とする共同体は、仲筋村の草分けで、幸 本御猚を祖神とする共同体は、仲筋村一の後入りだとされる。参考文献
8) pp. 87-89 参照。また、近年の氏子の居住構成は、玻座間村と仲筋村の 間で複雑になってきている。参考文献 12) pp. 9 参照。

注 13)神司の継承は、伯母から姪へ母から娘へ継いだり、嫁が継ぐ場合があるが、 最近では御䔻の世話役（カンマンガー）の蝊が継いだり、殿居元から出 嫁した娘が継ぐ場合もある。参考文献 9) pp. 149 および pp. 153-155 参照。 このように、婚姻関係の複雑化により、殿居元と神司の住居が異なる 場合が多い。

注 14）穂利祭において、村住人単位（東村・西村または、玻座間村・仲筋村の 住人）で祭祀に参加している。参考文献 16) pp. 64-65 参照。

注 15）竹富島に打ける御嶣一の所属は、同一家族内で異なり、他地域に比心 多様である。参考文献 14) pp. 254-257 参照。

注 16) 竹富島の結願祭は、「ユウニンガイ（四月大祭・西塘大祭・結願祭・九 月大祭)」と総称される祭祀形態に類型され、西塘御嶽・清明御获・幸 本御嶽で「夜籠もり(ユウグムイ)」が行われることが特徵である。参 考文献 11) pp.153-154 参照。また、上記 4 祭祀では、ほぼ同じ場所（22 カ 所の拝所）と過程で祈願が行われる。参考文献 pp. 136-138 参照。

注 17) 参考文献 15) pp. 11 と pp. 153 参照。

注 18） 2004 年 9 月 20 日・21 日に行われた結願祭において、筆者と調査協力者 1 人と手分けをし、祈願ルートと参加者の着座位置の記録を行った。ま た21日は、来訪神歓待の儀礼である「世迎い(ユーンカイ)」と重なっ たため、午前中に結願祭に㧍ける一連の御获での新願を終えた後、正午 過ぎに世迎いが行われ、その後に結願祭の奉納芸能が行われるという特 異な祭祀進行を経ている。

注 19） 2002 年から幸本御嶽の神司は不在だが、幸本御孰での夜籠りや、ニー ランでの祈願の際、別の神司や主事が幸本御䓑の神司が担ら供物を所定 位置に準備している。また、西美崎御訔の男司（オトコツカサ）は、仲 筋村生盛屋の家主が担当している。竹富島では、司と呼ぶ場合は女性 の神司のことを示し、男司と呼ぶ場合は、男性の神司を示す。参考文献 17) pp. 114-115 参照。参考文献 9) pp. 109 参照。

注 20「殿居穗利（オンプイ）」「四月大願い(シガッフーニンガイ）」「九月大 願い(クガチフーニンガイ)」「西塘ばんはじり」においては、神司と公 民館執行部が、村御獤とセットで幸本御獤での新願や夜籠りを行うこと から、幸本御猚は村御薃と同等な祈願対象として位置づけられる。参考 文献 16) pp. 65 や 9) pp. 136-138 参照。

注 21）内盛正子氏（花城御猄の神司）と、島仲由美子氏（仲筋御孰の神司）か らの聞き取りによる。

注 22) 1987 年の結願祭については、参考文献 11) pp. 153 参照。参考文献 18）pp. 104-106（1965 年の調査記録）の結願祭の記録では、美崎御䔻・ 東美崎御獤・西美崎御獤・ニーランへ分かれて祈願を行っていたという 記述がある。一方、同書に結願祭の類型であるユウニンガイ（四月・九

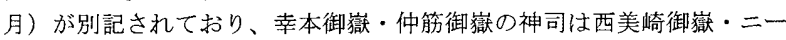
ランへ、玻利若御獤・花城御獤・久間原御猚の神司は東美崎御猚へ、玻 座間御嶽の神司は美崎御猚へ分かれて参择していたことが記録されてい る。このことから、1965 年当時の結願祭では 1987 年と同じ参拝分担の 方法が採られていたと考えられ、この分担方法は過去長年行われ、近年 になって再編されたことが解る。

注 23）参考文献 9) pp. 153-155 の上勢頭芳德氏による神司系譜図と参考文献 19)pp. 296-305 の神司の玍号名、および参考文献 12) pp. 19 の屋号図と照 らし合わせることで、1962 年ー 1972 年における神司の居住位置を明ら かにすことができる。

注 24）まず萃本御孰の神司（入仲本静氏）が 1977 年に引退、その後 1981 年に 久間原御嶣の神司（安里八重氏）が引退し、神司が 4 人となる。久間腹 御䓂に神司代理（田多幸子氏）が継いだが、実質的に司を勤めなかった。 1987 年以降、玻座間御猫の神司（石川明氏）・波利若御猚の神司（新苗氏） が引退し、玻座間御猄には神司の代理（根原康氏）が就いて、玻座間御薃・ 美崎御嶽・親泊御㟿のみの祈願を担っていたが、実質的な神司は、花城 御嶽の神司 (内盛正子氏)・仲筋御嶽の神司（登野原光氏）のみとなった。

注 25) 1991 年に波利若御獤の神司（新田初子氏）が着任した後、1995 年から玻 座間御獤の神司(富本定子氏)が着任し、1997 年から久間原御猚の神司 (与 那国光子氏）が着任し、現在に至る。また 2001 年に幸本御获の神司（請 盛ハル氏）が着任するが、1 年で引退する。参考文献 9) pp. 153-155 参照。 注 26）上勢頭芳徳氏による新田初子氏・内盛正子氏への聞き取りから。

\section{参考文献}

1）真栄田義見・三隅治雄・源武雄 編：沖縄文化史辞典，東京堂出版，1972

2) 沖縄大百科事典, 沖縄タイムス社, 1983

3）仲松弥秀：神と村，鳥社, 1990

4) 波照間永吉：南島祭祀歌謡の研究, 砂子屋書房, 1999

5）日本建築学会編：集住の知恵－美しく住むかたち一，技報堂出版，2005 
6）南風原町史委員会：「南風原 シマの民俗」，南風原町史第六巻 民俗資料編 , 2003

7）北中城村史編纂委員会：北中城村史，北中城村役場，1996

8）浦山隆一：沖綶八重山諸岛の村落信仰における伝統的祭祀施設の空間構 造に関する研究一聖なる空間の形態学序説一, 神戸芸術工科大学学位論文, 1999

9）益田兼房：東アジア周縁部の土着の聖なる空間に関する研究，科学研究費 補助金 [基盤研究 $\mathrm{A}$ ( I ) ] 研究成果報告書, 2003

10) 渋谷研：変貌する祭祀 一沖縄の女性祭祀集団の持続と再編に関する一考察 -, 沖縄民俗研究第 14 号, 沖縄民俗学会, 1994

11）刍井秀一：竹富島の歴史と民俗，角川書店，1990

12）竹富町教育委員会編 : 竹富島の集落と民家一竹富島伝統的建造物群保存地区 保存計画見直し調查報告書一, 竹富町, 2000

13）玉城 毅：竹富島の社会組織一祭祀からみた重層的・統合的な「村落」一, 地域研究シリーズ No. 28, 八重山、竹富島調查報告書 (2), 南島文化研究所 , pp. 39-74, 2000

14）谷川建一編：村落共同体・わが沖縄，第四巻, 1971

15）上勢頭 亨：竹富島誌一民話・民俗編-，法政大学出版局，1976

16）金城正紀・片山和俊・光井涉 : 竹富島における祭祀の機能と集落の空間構 成に関する研究一穂利祭 (プイ) の祭祀空間についてその1-, 日本建築学 会計画系論文集, No. 604, pp. 61-68, 2006. 6

17) 東京ソルボンヌ塾・宮沢智士編：竹富島に何か可能か, 喜宝院蒐集館 , 1996

18）琉球大学民俗研究クラブ編：沖縄民俗，第 10 号，第一書房，1988

19）中山盛茂・富村真演・宮城栄昌：のろ調查資料，ボーダーインク，1990

(2007年1月 9 日原稿受理，2007年 6 月 5 日採用決定) 